\title{
Inter-annual variability in water table depth controls net ecosystem carbon dioxide exchange in a boreal bog
}

\author{
Ian B. Strachan • Luc Pelletier • \\ Marie-Claude Bonneville
}

Received: 2 June 2015/Accepted: 3 December 2015/Published online: 26 December 2015

(C) The Author(s) 2015. This article is published with open access at Springerlink.com

\begin{abstract}
The net ecosystem carbon dioxide $\left(\mathrm{CO}_{2}\right)$ exchange (NEE) between boreal bogs and the atmosphere and its environmental drivers remains understudied despite the large carbon store of these northern ecosystems. We present NEE measurements using the eddy covariance technique in a boreal ombrotrophic bog over five growing seasons and four winters. Interannual variability in $\mathrm{CO}_{2}$ uptake was most pronounced in June-September ( -4 to $-122 \mathrm{~g} \mathrm{CO}_{2}-\mathrm{C} \mathrm{m}^{-2}$ ), less in March-May ( -1 to $-21 \mathrm{~g} \mathrm{CO}_{2}-\mathrm{C} \mathrm{m}^{-2}$ ) and very small in October-November ( -2 to $-4 \mathrm{~g} \mathrm{CO}_{2-}$ $\mathrm{C} \mathrm{m}^{-2}$ ). Variability in NEE between years was linked primarily to changes in water table depth (WTD). Strong and significant relationships $\left(\mathrm{r}^{2}>0.89\right.$, $\mathrm{p} \leq 0.05$ ) were found between summer (JuneSeptember) maximum photosynthetic rate $\left(A_{\max }\right)$, net ecosystem productivity (NEP), gross ecosystem productivity and WTD. Adding air temperature through multiple regression analysis further increased correlation between summer $A_{\max }$, NEP, and WTD $\left(\mathrm{r}^{2}=0.96, \mathrm{p}=0.05\right)$. In contrast to previous studies examining controls on peatland $\mathrm{CO}_{2}$ exchange, no relationships were found between productivity or
\end{abstract}

Responsible Editor: E. Veldkamp.

I. B. Strachan $(\square) \cdot$ L. Pelletier · M.-C. Bonneville Department of Natural Resource Sciences, McGill University, 21111 Lakeshore Road, Ste Anne de Bellevue, QC H9X 3V9, Canada

e-mail: ian.strachan@mcgill.ca cumulative exchange and early season temperature, timing of the snowmelt or growing season length.

Keywords Net ecosystem $\mathrm{CO}_{2}$ exchange · Peatland - Gross ecosystem productivity · Ecosystem respiration - Water table depth

\section{Introduction}

Boreal and subarctic peatlands are abundant in the Hudson Bay lowlands in Canada, and in the Western Siberian lowlands in Russia ( $\mathrm{Yu}$ et al. 2010). In Canada, the total peatland area is approximately $114 \times 10^{6}$ ha, of which $64 \%$ are found in boreal and $33 \%$ in subarctic regions (Tarnocai 2006). The prevailing cool and wet conditions in these regions favour the development of these ecosystems by promoting higher photosynthetic $\mathrm{CO}_{2}$ uptake over carbon (C) release resulting in long term net $\mathrm{C}$ accumulation (Clymo 1984). It is estimated that northern peatlands, globally covering approximately $400 \times 10^{6}$ ha, represent a $\mathrm{C}$ storage of between 473 and 621Pg C (Yu et al. 2010). These ecosystems are therefore unique components of the global $\mathrm{C}$ cycle, and consequently of the global climate, especially on longer time scales. Over the Holocene, peatland development and expansion has had an impact on the atmospheric $\mathrm{CO}_{2}$ and has also contributed to increasing atmospheric methane $\left(\mathrm{CH}_{4}\right)$ concentrations (Macdonald et al. 2006; Yu et al. 2013). 
Northern peatlands are generally small to moderate net annual $\mathrm{C}$ sinks but can also act as net sources of $\mathrm{C}$ to the atmosphere depending on the hydro-meteorological conditions and the relative contribution of different components of the peatland $\mathrm{C}$ budget $\left[\mathrm{CO}_{2}\right.$, $\mathrm{CH}_{4}$ and dissolved organic carbon (DOC)] (e.g. Roulet et al. 2007; Koehler et al. 2011). The net ecosystem $\mathrm{CO}_{2}$ exchange (NEE) generally represents the largest and most variable component of the peatland $\mathrm{C}$ budget between years (e.g. Roulet et al. 2007); the interannual variability in NEE can vary by an order of magnitude at some locations (e.g. -2 to $-112 \mathrm{~g} \mathrm{CO}_{2}-$ $\mathrm{C} \mathrm{m}^{-2}$ year $^{-1}$; Roulet et al. 2007). Lower annual NEE generally corresponds with years where growing season water table drops due to limited precipitation (Roulet et al. 2007; Koehler et al. 2011; Peichl et al. 2014). While Peichl et al. (2014) observed a strong decrease in gross ecosystem productivity (GEP) when WTD was below $30 \mathrm{~cm}$, they also found growing season GEP to be strongly correlated with pre-growing season air temperature. Warmer pre-growing season temperatures were associated with shallower frost penetration in the peat, producing less root damage, and allowing better access to water and nutrients, enhancing productivity (Peichl et al. 2014). In the Kaamanen subarctic fen, Aurela et al. (2004) found timing of the snow-melt and spring temperature to be the most important controls on determining annual $\mathrm{CO}_{2}$ balance, with earlier snow-melt and higher spring temperature resulting in higher annual $\mathrm{CO}_{2}$ sequestration. However, as highlighted by Peichl et al. (2014) there are currently a limited number of published studies with long-term records (5 years or more) of NEE. Those sites include the Kaamanen subarctic fen (Aurela et al. 2004), the Mer Bleue temperate bog near Ottawa, Canada (Roulet et al. 2007), a moderately rich treed fen in Alberta, Canada (Flanagan and Syed 2011), an Atlantic blanket bog in Ireland (Koehler et al. 2011), a boreal oligotrophic minerogenic mire (Nilsson et al. 2008; Peichl et al. 2014) and a temperate ombrotrophic peatland in South East Scotland (Helfter et al. 2015). Considering that the northern peatland $\mathrm{C}$ pool corresponds to more than $50 \%$ of the $\mathrm{C}$ found in the atmosphere as $\mathrm{CO}_{2}$, the number of multi-year studies that have examined the controls on inter-annual variability in NEE is quite limited. Understanding the drivers of measured interannual variability in peatland $\mathrm{C}$ dynamics is very important for making advances in global change studies. Increasing the variety of climates, vegetation types and locations covered by longer-term studies improves the development of models used to estimate regional and global $\mathrm{C}$ budgets. These in turn provide essential components to global climate change studies for predictions of impacts on ecosystem functioning and potential consequences for ecosystem $\mathrm{C}$ budgets. To date, the few published long-term studies on peatland NEE have focussed on fens or oceanic and temperate bogs. They do not cover the dominant peatland region or type-boreal bogs. In Canada, $64 \%$ of the $\mathrm{C}$ stored in peatlands is found in the boreal region where bog peatlands dominate (Tarnocai 2006). It is therefore imperative to identify the main controls on NEE in this peatland type in order to be able to model their response to climate change.

In this study, we measured NEE using the eddy covariance (EC) technique in a boreal bog between June 2008 and October 2012. The main objectives were to: assess the inter-annual variability in NEE and its components (gross photosynthesis and respiration); identify how the environmental controls such as WTD and temperature affect this variability; and to evaluate the $\mathrm{CO}_{2}-\mathrm{C}$ sink strength of this boreal bog peatland.

\section{Materials and methods}

\section{Site description}

The study site is the Lac Le Caron (hereafter referred to as LLC) peatland, an ombrotrophic bog located in a humid mid-boreal climate in the James Bay region of Northwestern Quebec, Canada $\left(52^{\circ} 17^{\prime} 25^{\prime \prime} \mathrm{N}\right.$; $\left.75^{\circ} 50^{\prime} 15^{\prime \prime} \mathrm{W}\right)$. The study site is relatively remote being only accessible by helicopter. The basal date of this peatland is estimated to be $7500 \mathrm{cal} \mathrm{BP}$, with the deepest part reaching $5.3 \mathrm{~m}$ (van Bellen et al. 2011). The peatland covers approximately $2.47 \mathrm{~km}^{2}$ and its surface is characterized by a hummock-lawn-hollow pattern. The vegetation biomass decreases along the hummock to hollow microtopographic gradient. Hummock vegetation is mainly dominated by Sphagnum fuscum and shrubs (e.g. Kalmia angustifolia, Picea mariana, Chamaedaphnee calyculata). Sphagnum fallax and Carex spp. dominate the vegetation on the lawns, while Sphagnum cuspidatum with more limited vascular vegetation biomass are found in hollows. More details on the aboveground biomass and species 
can be found in Pelletier et al. (2011). Long-term temperature and precipitation data for the region are non-existent. The closest station with a 30-year climate normal is located approximately $200 \mathrm{~km}$ northwest of the study site at the La Grande rivière airport. The second nearest is the Chibougamau Chapais airport, which is $300 \mathrm{~km}$ southeast of the studied peatland. However, interpolated mean and standard deviation for the 1971-2000 period (National Land and Water Information Service (NLWIS), Hutchinson et al. 2009) show the regional mean annual temperature to be $-2.3 \pm 1.1^{\circ} \mathrm{C}$, with the coldest and warmest months being January $\left(-22.1 \pm 2.6{ }^{\circ} \mathrm{C}\right)$ and July $\left(14.6 \pm 1.1{ }^{\circ} \mathrm{C}\right)$, and the mean annual precipitation to be $735 \pm 66 \mathrm{~mm}$.

\section{Instrumentation and flux calculations}

The EC technique was used to measure fluxes of $\mathrm{CO}_{2}$ $\left(\mathrm{F}_{\mathrm{c}}\right)$. The EC system consisted of a three-dimensional sonic anemometer-thermometer (CSAT-3, Campbell Scientific, Logan, UT), an open-path infrared gas analyzer (IRGA; Li-7500, LI-COR, Lincoln, NE) and a fine wire thermocouple (FW03, Campbell Scientific, Logan, UT). The instruments were mounted on a tripod at $2.75 \mathrm{~m}$ above the ground and aligned in the dominant wind direction. EC data were stored on compact flash cards using a data logger (CR5000, Campbell Scientific, Logan, UT) and were retrieved as logistics allowed. Fluxes were measured at $10 \mathrm{~Hz}$, but sampling frequency was reduced to $5 \mathrm{~Hz}$ from November to April due to limited access to retrieve data cards during the winter.

The turbulent $\mathrm{C}$ flux was calculated as the covariance of the deviation around the mean of vertical wind speed and the concentration of $\mathrm{CO}_{2}$ (Baldocchi 2003). A two-axis coordinate rotation was applied (Baldocchi 1997), de-spiking was performed using the high frequency data (Vickers and Mahrt 1997), and detrending was done using the block average method (Baldocchi 2003). Finally, the effect of fluctuations in air density was removed (Webb et al. 1980). The storage flux $\left(\mathrm{F}_{\mathrm{s}}\right)$ was calculated based on Morgenstern et al. (2004), and the NEE was obtained by adding $F_{s}$ to $F_{c}$. Negative NEE values indicate a net uptake of $\mathrm{CO}_{2}$ by the ecosystem, whereas positive values represent a net release of $\mathrm{CO}_{2}$ to the atmosphere. Supporting measurements of meteorological variables included incoming and outgoing solar and longwave radiation (CNR-1; Kipp and Zonen, Delft, Netherlands), incoming and reflected photosynthetically active radiation (PAR; LI-190SB; LI-COR, Lincoln, NE), soil heat flux (HFT3; Campbell Scientific, Logan, UT), precipitation (TE525 M tipping bucket rain gage; Texas Electronics, Dallas, TX), wind speed and direction (wind monitor 05103; RM Young, Traverse City, $\mathrm{MI})$, air temperature $\left(\mathrm{T}_{\text {air }}\right)$ and relative humidity (HC-S3; Campbell Scientific, Logan, UT), and soil temperature $\left(\mathrm{T}_{\text {soil }}\right)$ at 5, 10, 20, and 40 (type $\mathrm{T}$ thermocouples). All environmental variables were measured at $0.5 \mathrm{~Hz}$ and 30-min averages were stored on a data logger (CR23X, Campbell Scientific, Logan, UT). WTD was measured continuously at a low hummock location (Ecotone WM $2.0 \mathrm{~m}$ Water Level Monitor, Remote Data Systems, Inc., Navassa, NC).

Data processing, quality control and gap filling procedures

We used an in-house Matlab (Mathworks, Natick, MA) script to do a first automated quality control of the 30-min flux and climate data following the established FCRN (Fluxnet-Canada Research Network) guidelines (Lafleur et al. 2003; Roulet et al. 2007). The quality control procedure followed Bergeron and Strachan (2011) and included the removal of raw high-frequency data spikes (Vickers and Mahrt 1997) and out-of-range data points (e.g. air $\mathrm{CO}_{2}$ concentration below $300 \mathrm{ppm}$ ). Half-hourly out of range values $\left(\mathrm{CO}_{2}\right.$ fluxes: -40 to $+40 \mu \mathrm{mol} \mathrm{m}{ }^{-2} \mathrm{~s}^{-1}$ and latent heat fluxes: -250 to $+1000 \mathrm{~W} \mathrm{~m}^{-2}$ ) were also discarded. Data falling into a period of known instrument malfunction or servicing were eliminated. These periods mainly occurred between November and March when snow accumulation on the solar panels, combined with cold temperatures, would result in power loss to the EC system. The built-in IRGA diagnostic signal was used to identify unreliable data due to obstruction of the IRGA's path. Nighttime (defined as incoming shortwave radiation $<10$ $\mathrm{W} \mathrm{m}{ }^{-2}$ ) $\mathrm{CO}_{2}$ flux data were rejected when friction velocity $\left(\mathrm{u}_{*}\right)$ was below the threshold value of $0.08 \mathrm{~m} \mathrm{~s}^{-1}$; determined using the technique described in Mkhabela et al. (2009). This threshold was also corroborated through visual inspection by plotting nighttime $\mathrm{F}_{\mathrm{c}}$ against $\mathrm{u}_{*}$ and identifying the $\mathrm{u}_{*}$ value beyond which $\mathrm{u}_{*}$ and $\mathrm{CO}_{2}$ fluxes are no longer related. Between June 2008 and October 2012, $59 \%$ of the 
data were rejected including those failing the friction velocity threshold criteria. Of this total, $61 \%$ of the rejected periods were nighttime.

Small gaps ( $\leq$ four half-hours) in environmental and flux data were filled by linear interpolation. Longer gaps in $\mathrm{T}_{\text {air }}, \mathrm{T}_{\text {soil }}$, incoming PAR, precipitation and incoming shortwave radiation were filled using relationships with the corresponding variables measured at two nearby study sites (within $10-15 \mathrm{~km}$ of the peatland). Filling longer gaps ( $>4$ half-hours) in the eddy covariance time series was completed based on the standard FCRN gap filling methods developed and widely used by the flux community (e.g. Barr et al. 2004; Lafleur et al. 2003). Ecosystem respiration (ER) was estimated based on annual logistic relationships between nighttime NEE and $\mathrm{T}_{\text {soil }}$ at $5 \mathrm{~cm}$. These relationships were used to model growing season daytime ER, missing nighttime NEE, and cold season NEE. Gross ecosystem productivity (GEP) was calculated from modeled ER and measured NEE (i.e. ER-NEE). A hyperbolic relationship between measured GEP and incoming PAR was used to model GEP based on the peak productivity period (Lafleur et al. 2001). Time variation in the ER and GEP model parameters was taken into account by using moving windows of 100 points. The ER and GEP models were applied on a 30-min basis and the remaining NEE gaps were filled by subtracting GEP from ER.

Users of open-path IRGAs (LI-7500) have reported occasional $\mathrm{CO}_{2}$ uptake during the cold season, when photosynthesis is improbable (Amiro 2010; Hirata et al. 2007; Lafleur and Humphreys 2008; Mkhabela et al. 2009). This problem has been attributed to the surface heating of the IRGA body by the electronics, which generates an additional sensible heat flux (Burba et al. 2008; Grelle and Burba 2007). We used the winter regression presented in Amiro (2010) for data corresponding with temperature below $0{ }^{\circ} \mathrm{C}$. Although the method eliminated cold period $\mathrm{CO}_{2}$ uptake, the resulting peatland winter $\mathrm{CO}_{2}$ loss was relatively small compared to other studies reporting cold season $\mathrm{CO}_{2}$ exchange data using closed path $\mathrm{CO}_{2}$ analysers. We report estimated annual NEP, GEP and ER for our site with the caveat that our cumulative values most likely underestimate winter $\mathrm{CO}_{2}$ loss. We therefore focus our analysis on the April to November data. In reporting the annual $\mathrm{C}$ balance, we consider the years to be from November 1st to October 31st (see Roulet et al. 2007). For the initial year between November 2007 and June
2008, we used an average NEE measured over the same months during the following 4 years. The annual NEP uncertainty was evaluated as the square root of the sum of a $20 \%$ error calculated for each 30-min flux data for both measured and gap filled data (Morgenstern et al. 2004; Nilsson et al. 2008).

\section{NEE data analysis}

NEE in peatlands is equal to the difference between the gross ecosystem productivity (GEP, photosynthesis by the surface vegetation), and the ecosystem respiration (ER, composed of autotrophic [growth and maintenance] and heterotrophic [peat decomposition] respiration). NEE data were fit to:

$$
\begin{gathered}
N E E-\mathrm{CO}_{2}=-\frac{\alpha \cdot P A R \cdot A_{\max }}{\alpha \cdot P A R+A_{\max }}+R_{10} \\
\cdot e^{308.56\left[\frac{1}{56.02}-\frac{1}{T-227.13}\right]} ;
\end{gathered}
$$

where the first term represents gross productivity as a rectangular hyperbolic relationship (Frolking et al. 1998) with $A_{\max }$ being the maximum photosynthesis rate and $\alpha$ the initial quantum yield. The second term represents ER and is based on an exponential temperature response model (Lloyd and Taylor 1994) using the nighttime NEE (assumed to be equivalent to ecosystem respiration, ER), where $R_{10}$ is the respiration rate at $10{ }^{\circ} \mathrm{C}$ and $\mathrm{T}$ is $\mathrm{T}_{\text {air }}$ in K. Equation (1) was parameterized $\left(\alpha, A_{\max }\right.$, and $\left.R_{10}\right)$ with measured NEE, PAR, and $\mathrm{T}_{\text {air }}$ using non-linear least-squares regression in the MATLAB computing environment (Matlab, v7.10.0.499 (R2010a), MathWorks, Matick, MA, USA).

\section{Results}

Inter-annual hydro-meteorological variability

The 2008 to 2012 mean annual temperatures varied between -1.4 and $1.3{ }^{\circ} \mathrm{C}$ and were above the 1971-2000 average of $-2.3 \pm 0.2{ }^{\circ} \mathrm{C}$ (NLWIS, Hutchinson et al. 2009). The coldest and warmest years were 2009 and 2010 respectively. The monthly average temperatures varied between years with largest differences measured between November and April (Fig. 1). The monthly average temperature and precipitation anomalies for May to October 2008 to 2012 show that months in 2008 (with the exception of September) were warmer and wetter than the 

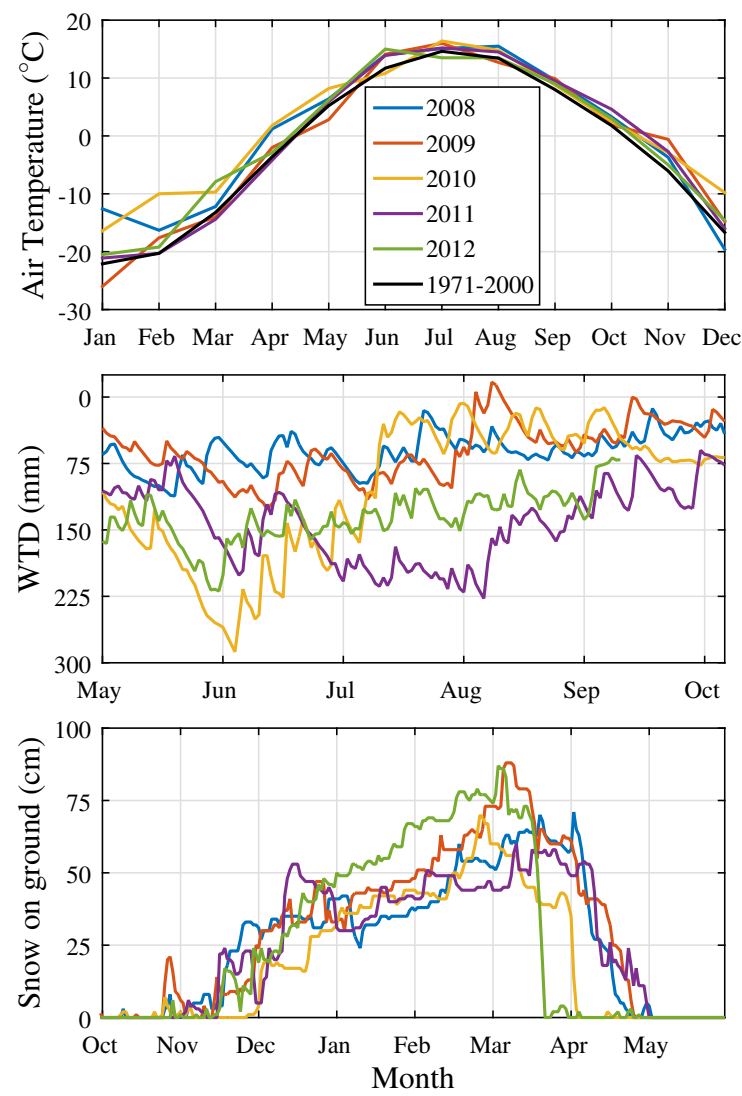

Fig. 1 Top panel mean monthly (2008-2012), and 30-year, temperatures $\left({ }^{\circ} \mathrm{C}\right)$ in the Eastmain- 1 region; middle panel midMay to late October (2008-2012) water table depth (WTD; $\mathrm{mm})$; bottom panel thickness of the snow layer on the ground (cm) (2007-2008 to 2011-2012). (Color figure online)

1971-2000 average (Fig. 2). The 2008 May to October temperatures were higher than normal by 0.4-1.5 ${ }^{\circ} \mathrm{C}$. Over the five growing seasons, precipitation was closest to the 30-year average in 2009, 2011 and 2012, with less than $20 \mathrm{~mm}$ difference, while 2008 was wetter by $116 \mathrm{~mm}$, and 2010 dryer by $139 \mathrm{~mm}$. Precipitation was not measured during the cold periods. Instead, the precipitation data from Environment Canada's Chibougamau station was used. The November to April precipitation was lowest in 2009-2010 with $294 \mathrm{~mm}$, compared to a range of 420-464 mm for the other cold periods. Despite a slower start, the 2009-2010 snow accumulation on the ground was similar to the other years (Fig. 1). The timing of the snowmelt varied between years; late March for 2009-2010, early April in 2011-2012, compared to late April and early May for the other

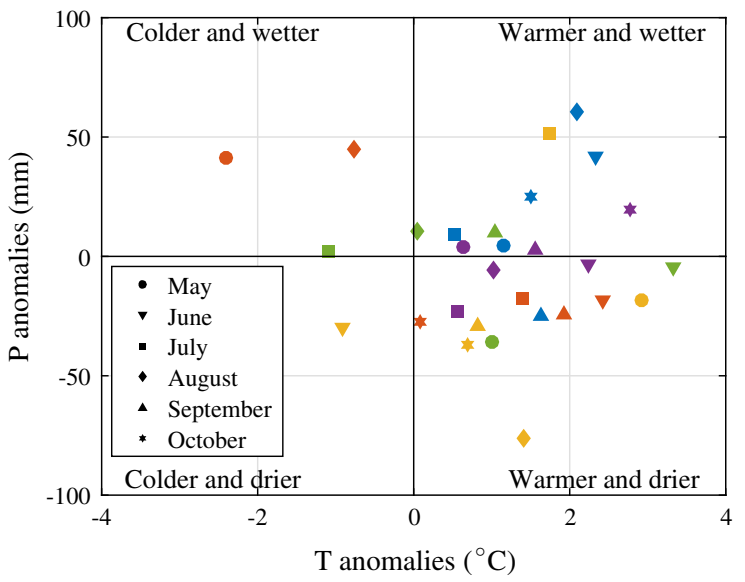

Fig. 2 Temperature $\left({ }^{\circ} \mathrm{C}\right)$ and precipitation $(\mathrm{mm})$ anomalies (May-October) during the measurement period compared with the 30-year average (1971-2000) at the studied peatland. Months are distinguished by the different shapes as indicated in the legend. The colour of the symbol indicates the year as follows: 2008-blue; 2009—orange; 2010-yellow; 2011purple; 2012_ green. (Color figure online)

years (Fig. 1). The inter-annual variability in hydrometeorological conditions had impacts on the WTD. As a result, the WTD was closest to the surface during 2008 and 2009, with June to September average depth relative to the surface of 65 and $67 \mathrm{~mm}$, respectively, while the greatest June to September WTD were observed in 2011 and 2012 (155 and $134 \mathrm{~mm}$ ) (Fig. 1). With the exception of 2008, the peatland WTD moved away from the surface during June each year (Fig. 1).

Growing season length was evaluated following Lund et al. (2010). The growing season represents the period where vegetation takes up $\mathrm{CO}_{2}$, as opposed to the $\mathrm{C}$ uptake period, which represents the period where the ecosystem is a net sink for $C$. The start of the growing season was expressed as the first day of a period where mean daily $\mathrm{T}_{\text {air }}$ rises above $5{ }^{\circ} \mathrm{C}$ for seven consecutive days. Consequently, the end of the growing season was established as the first day of seven consecutive days with $\mathrm{T}_{\text {air }}$ below $5{ }^{\circ} \mathrm{C}$. The 2008-2012 growing seasons were found to start on May 30, June 8, May 13, May 17 and May 19, and ended on September 11, September 17, September 17, September 8 and September 12, for 2008 through 2012, respectively. The length of the growing season was therefore 104, 102, 128, 115 and 116 days from 2008 to 2012, respectively, with the difference 
between years mainly being controlled by the start date of the growing season rather than the end.

$\mathrm{CO}_{2}$ exchange

\section{Photosynthesis and respiration}

There was significant variability between the 5 years' monthly average $A_{\max }$, evaluated using Eq. 1 (see Section "NEE data analysis"). Note that for June, we restricted the comparison to the second half of the month (June 15-30) because of the lack of data in the initial year (early June 2008). The $2008 A_{\max }$ monthly values were higher than corresponding values in the following years with the exception of June and July 2009, which were not statistically different (Table 1). The largest difference can be observed when comparing 2008 with 2011 and 2012. During the last two growing seasons, $A_{\max }$ was less than half that measured in 2008 for the same months. Overall, the general trend shows that the monthly $A_{\max }$ decreased from 2008 to 2012, with the exception of September, likely because of the different timing of senescence. The inter-annual variability in the June to September
$A_{\max }$ was strongly correlated with the average WTD for the same period $\left(\mathrm{r}^{2}=0.89, \mathrm{p}=0.02\right)$, with $A_{\max }$ increasing as WTD decreased (moved closer to the surface). The monthly average $A_{\max }$ increase from June to August 2010 also corresponds with WTD getting closer to surface. Air temperature and WTD combined resulted in a significant relationship with $A_{\text {max }}\left(\mathrm{r}^{2}=0.96, \mathrm{p}=0.05\right)$.

The variability in $R_{10}$ between the five years followed a similar but less pronounced pattern than the one observed for $A_{\max }$ (Table 1). The $R_{10}$ values generally increased from June to July before decreasing until September. The largest decrease was observed between July and August 2009 where $R_{10}$ decreased by more than $50 \%$ (Table 1 ). This sharp decrease corresponds with the water table moving closer to the surface in August 2009, which potentially reduced the heterotrophic component of ER as the peat layer became completely saturated and therefore anoxic. Note that the lowest $R_{10}$ value was measured in September of the same year and could suggest that microbial fauna were not able to replenish after the water table moved away from the surface, possibly as a result of colder temperatures experienced in late
Table 1 Equation 1 fit parameters for the summer months at the Lac le Caron (LLC) Peatland, 2008-2012

\begin{tabular}{|c|c|c|c|c|c|c|}
\hline Year & Month & $\mathrm{n}$ & $\begin{array}{l}\alpha \\
\mathrm{mol} \mathrm{CO} \\
\mathrm{CO}_{2} / \mathrm{mol} \mathrm{PAR}\end{array}$ & $\begin{array}{l}A_{\max } \\
\mu \mathrm{mol} \mathrm{m} \mathrm{m}^{-2} \mathrm{~s}^{-1}\end{array}$ & $\begin{array}{l}R_{10} \\
\mu \mathrm{mol} \mathrm{m}{ }^{-2} \mathrm{~s}^{-1}\end{array}$ & $r^{2}$ \\
\hline \multirow[t]{4}{*}{2008} & June & 339 & $0.028(0.022,0.034)$ & $5.9(5.5,6.3)$ & $0.85(0.73,0.96)$ & 0.78 \\
\hline & July & 848 & $0.033(0.029,0.037)$ & $7.7(7.4,8.1)$ & $0.90(0.80,0.99)$ & 0.79 \\
\hline & August & 778 & $0.030(0.026,0.033)$ & $7.9(7.5,8.2)$ & $0.85(0.78,0.92)$ & 0.84 \\
\hline & Sept & 791 & $14,0.018)$ & 518 & $50,0.62)$ & 0.79 \\
\hline \multirow[t]{4}{*}{2009} & June & 510 & $0.026(0.021,0.031)$ & $5.6(5.3,5.9)$ & $0.81(0.74,0.89)$ & 0.74 \\
\hline & July & 890 & $0.038(0.033,0.042)$ & $7.6(7.2,7.9)$ & $1.05(0.97,1.13)$ & 0.79 \\
\hline & August & 734 & $0.014(0.011,0.017)$ & $6.2(5.6,6.7)$ & $0.48(0.38,0.58)$ & 0.69 \\
\hline & September & 667 & $0.011(0.008,0.014)$ & $2.4(2.2,2.6)$ & $0.29(0.23,0.35)$ & 0.61 \\
\hline \multirow[t]{4}{*}{2010} & June & 492 & $0.012(0.009,0.014)$ & $4.5(4.1,4.9)$ & $0.63(0.55,0.72)$ & 0.72 \\
\hline & July & 733 & $0.020(0.017,0.023)$ & $5.0(4.7,5.2)$ & $0.73(0.67,0.80)$ & 0.75 \\
\hline & August & 632 & $0.022(0.019,0.025)$ & $5.4(5.1,5.7)$ & $0.74(0.67,0.80)$ & 0.80 \\
\hline & September & 749 & $0.017(0.014,0.020)$ & $3.6(3.3,3.9)$ & $0.58(0.52,0.65)$ & 0.73 \\
\hline \multirow[t]{4}{*}{2011} & June & 398 & $0.015(0.010,0.019)$ & $3.5(3.2,3.7)$ & $0.60(0.50,0.69)$ & 0.64 \\
\hline & July & 887 & $0.016(0.012,0.020)$ & $3.1(2.8,3.3)$ & $0.74(0.67,0.80)$ & 0.51 \\
\hline & August & 795 & $0.014(0.011,0.016)$ & $2.5(2.3,2.6)$ & $0.66(0.63$ & 0.73 \\
\hline & September & 707 & $0.013(0.009,0.018)$ & $1.6(1.5,1.8)$ & $0.59(0.53,0.65)$ & 0.48 \\
\hline \multirow[t]{4}{*}{2012} & June & 416 & $0.016(0.012,0.019)$ & $2.9(2.7,3.2)$ & $0.60(0.54,0.66)$ & 0.73 \\
\hline & July & 385 & $0.021(0.016,0.025)$ & $3.3(3.1,3.5)$ & $0.75(0.67,0.83)$ & 0.77 \\
\hline & August & 716 & $0.022(0.018,0.027)$ & $2.9(2.7,3.1)$ & $0.59(0.54,0.65)$ & 0.68 \\
\hline & September & 498 & $0.013(0.011,0.016)$ & $3.2(2.9,3.4)$ & $0.43(0.38,0.49)$ & 0.76 \\
\hline
\end{tabular}


summer. Overall, the average June to September $R_{10}$ was higher in 2008 at $0.71 \mu \mathrm{mol} \mathrm{m} \mathrm{m}^{-2} \mathrm{~s}^{-1}$ but did not vary significantly between 2009-2012, with a range of $0.58-0.60 \mu \mathrm{mol} \mathrm{m} \mathrm{s}^{-2}$.

\section{NEE, GEP and ER}

The spring (April-May) NEP for the 2009 to 2012 varied between $-1.0 \mathrm{~g} \mathrm{CO}_{2}-\mathrm{C} \mathrm{m}^{-2}$ in 2012 to a maximum uptake of $-21.4 \mathrm{~g} \mathrm{CO}_{2}-\mathrm{C} \mathrm{m}^{-2}$ in 2010 (Fig. 5) and the inter-annual variability was explained by a combination of factors $\left(\mathrm{T}_{\text {air }}\right.$, timing of the snowmelt and WTD). The largest (2010) spring cumulative $\mathrm{CO}_{2}$ uptake corresponded with higher than normal temperatures in both April and May (Fig. 1) and the second earliest snow melt of all five springs (Fig. 1). In contrast, the lowest spring $\mathrm{CO}_{2}$ was measured in 2012 and corresponded with the year where the earliest snowmelt was observed, with most of the snowpack disappearing in late March. The earlier snowmelt observed in 2012 was caused by warmer than normal temperatures between March 16 and 22. During that period, daily average temperatures were above $0{ }^{\circ} \mathrm{C}$, reaching 10.2 and $6.8{ }^{\circ} \mathrm{C}$ on March 20 and 21 st respectively. Following this warm period, the temperatures remained close to normal with daily average temperature going back down to $-17^{\circ} \mathrm{C}$ on March 26. The cold temperatures combined with the thin snow layer on the ground promoted deeper frost penetration in early April, with temperatures going down to $-1{ }^{\circ} \mathrm{C}$ at $20 \mathrm{~cm}$ below peat surface. Moreover, the early snowmelt was also combined with lower than normal precipitation in May (Fig. 2) resulting in the largest WTD of all the spring (May) periods (Fig. 1). The second lowest NEE (measured in spring 2009) corresponded with colder than normal temperatures and late April snowmelt. Both these elements potentially delayed plant development and reduced phenological activity and photosynthetic capacity. Finally, the second largest spring NEE uptake (measured in 2011) corresponded with a relatively late snowmelt, and close to normal temperatures and precipitation.

The average cumulative summer (June to September) NEP (mean $\pm \mathrm{SD}$ ) was $-59.1 \pm 41.7 \mathrm{~g} \mathrm{CO}_{2-}$ $\mathrm{C} \mathrm{m}^{-2}$ and was highly variable between years, ranging from to -4.1 to $-122.5 \mathrm{~g} \mathrm{CO}_{2}-\mathrm{C} \mathrm{m}^{-2}$. The site was a sink for $\mathrm{CO}_{2}$ during the summer periods with the exception of 2011, where the site was a small sink only in June and July ( -7.3 and $\left.-2.5 \mathrm{~g} \mathrm{CO}_{2}-\mathrm{C}\right)$ and a small net source in August and September (4.7 and $1.0 \mathrm{~g}$ $\mathrm{CO}_{2}-\mathrm{C}$ ). The monthly summer GEP pattern resembled that of $A_{\max }$ (Table 1; Fig. 3), with slight differences explained by the fact that $A_{\max }$ values are calculated at maximum light, while GEP is dependent on PPFD. The monthly average variability in ER was less pronounced than for GEP but the June to September period average ER followed a similar pattern, decreasing from 2008 to 2012.

The summer NEP was strongly correlated with the average WTD $\left(\mathrm{r}^{2}=0.92, \mathrm{p}=0.01\right)$, with the largest and smallest cumulative NEP values corresponding to 2008 and 2011 respectively (Fig. 4). Adding mean summer $\mathrm{T}_{\text {air }}$ to WTD through multiple regression analysis increased correlation to $0.96(\mathrm{p}=0.05)$. Addition of summer total precipitation and/or total PPFD resulted in non-significant correlations. The inter-annual variability in summer NEP was mainly the result of variability in GEP as opposed to ER. The cumulative GEP range was 140-288 $\mathrm{g} \mathrm{CO}_{2}-\mathrm{C} \mathrm{m}^{-2}$ period $^{-1}$, compared with 121-166 $\mathrm{g} \mathrm{C} \mathrm{m}^{-2}$ period $^{-1}$ for ER. The relationship between summer GEP and the average WTD was strong and significant $\left(\mathrm{r}^{2}=0.89\right.$, $\mathrm{p}=0.02$ ) while the relationship for ER was not significant $\left(r^{2}=0.64, p=0.10\right)$ (Fig. 4). This therefore suggests that autotrophic respiration dominated ER. Correlation through multiple regression analysis did not improve prediction of either summer GEP or ER. In contrast to Peichl et al. (2014), we did not find that the pre-growing season (January to April) mean air temperature explained inter-annual variability in

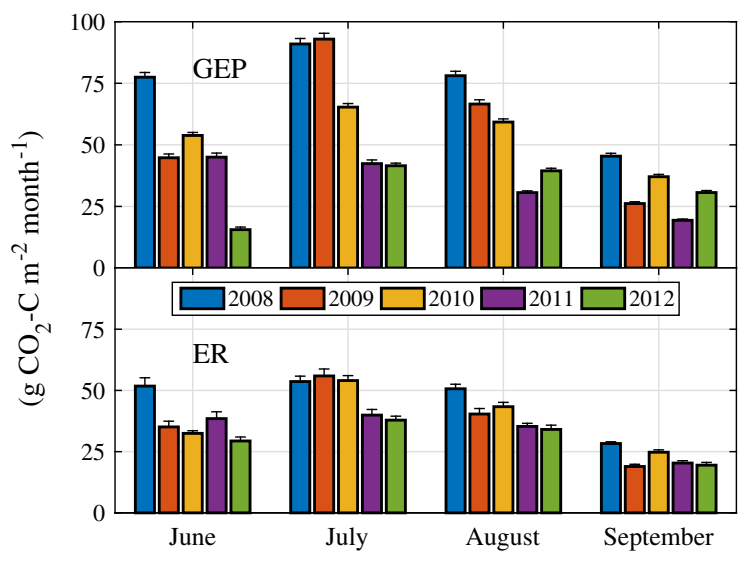

Fig. 3 June-September monthly GEP and ER between 2008 and 2012. Error bars represent the standard deviation from the mean. (Color figure online) 


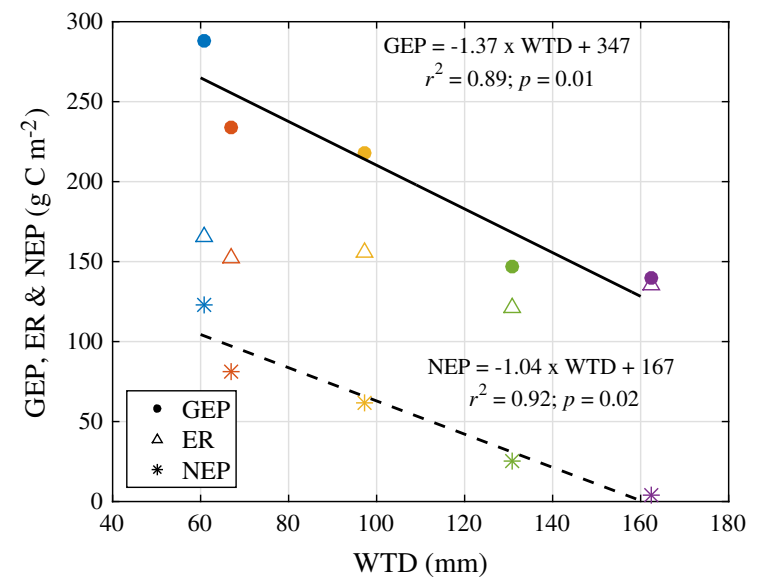

Fig. 4 Relationships between summer (June-September) GEP, ER, NEP and WTD

mean daily June-July GEP or ER (GEP : $\mathrm{r}^{2}=0.13$; ER: $\left.r^{2}=0.01\right)$, nor did it explain the variability in GEP or ER for any individual summer month or month pair.

The fall NEE was relatively small and showed limited variability between the years with a range of 2.4-4.2 $\mathrm{CO}_{2}-\mathrm{C} \mathrm{m}^{-2}$. This range is smaller than that observed for the spring. In the fall, ER is decreased by plant senescence, triggered by reduced temperature and light availability (Smart 1994). In the spring, as light becomes more available, the temperature and the thickness of the snowpack indirectly trigger the $\mathrm{CO}_{2}$ uptake by the vegetation (Aurela et al. 2004). While this corresponds with the greater variability at the beginning of the growing season compared to the end, we observed no relationship between the growing season length and the total $\mathrm{CO}_{2}-\mathrm{C}$ uptake at our site. Because the modeled winter $\mathrm{CO}_{2}$ loss was small $(<1 \mathrm{~g}$ $\mathrm{CO}_{2}-\mathrm{C} \mathrm{m}^{-2}$ period $\left.^{-1}\right)$ during four winters of measurements (December-March), the winter loss had a very limited impact on the annual NEP (Fig. 5; Table 2). The variability in NEP between years was dictated by the summer period $\mathrm{C}$ uptake.

\section{Discussion}

The LLC peatland NEE results presented here are among the first multi-year datasets for a boreal bog. Previously, Humphreys et al. (2014) presented 2-years of NEE for two bogs located in the Hudson Bay

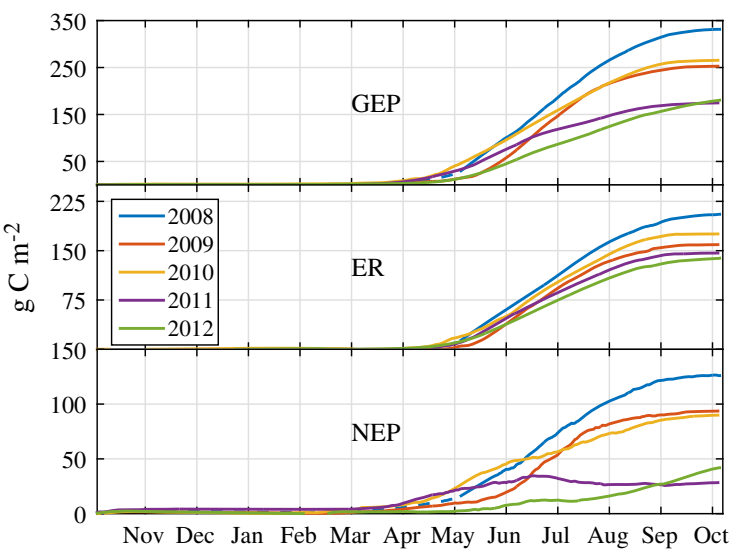

Fig. 5 Annual cumulative GEP, ER and NEP between November 1st, 2007 and October 31st, 2012 at the studied peatland. The pre-study period (November 2007-June 2008) GEP, ER and NEP were estimated using the average over the same months for the four subsequent years. (Color figure online)

Table 2 Annual cumulative GEP, ER and NEP between November 1st 2007 and October 31st 2012 at the LLC peatland

\begin{tabular}{lrll}
\hline Hydrological year & \multicolumn{1}{l}{ NEP } & ER & GEP \\
\hline $2007-2008$ & $126( \pm 9)$ & $205( \pm 9)$ & $332( \pm 3)$ \\
$2008-2009$ & $94( \pm 9)$ & $159( \pm 10)$ & $253( \pm 3)$ \\
$2009-2010$ & $90( \pm 6)$ & $176( \pm 7)$ & $266( \pm 3)$ \\
$2010-2011$ & $28( \pm 5)$ & $146( \pm 7)$ & $175( \pm 3)$ \\
$2011-2012$ & $42( \pm 5)$ & $138( \pm 6)$ & $181( \pm 2)$ \\
\hline
\end{tabular}

November 2007-June 2008 GEP, ER and NEP were estimated using the average measured over the same months over the four following years

lowlands. There have been long-term measurements (more than 4-years) from a temperate bog (Lafleur et al. 2003; Roulet et al. 2007), a minerogenic fen (Sagerfors et al. 2008; Nilsson et al. 2008; Peichl et al. 2014), palsa mire (Aurela et al. 2001, 2002, 2004), blanket bog (Sottocornola and Kiely 2010; Koehler et al. 2011) and treed fen (Flanagan and Syed 2011). Bog peatlands are the dominant peatland type in boreal regions of Canada where $64 \%$ of Canadian peatland are found (Tarnocai 2006). Multi-year datasets from these ecosystems are essential in order to identify how changes in climate may affect the $\mathrm{CO}_{2}$ exchange and $\mathrm{C}$ sequestration in these boreal peatlands. The results presented here show a large variability in NEE between years strongly linked to the change in WTD, and further explained by variability in temperature. 
The summer average $A_{\max }$, GEP and NEP (summer and annual) were strongly correlated with average WTD. Previous chamber measurements performed at the same site showed that as WTD decreased (i.e. moving closer to the surface), maximum rates of photosynthesis increased on hummocks (Pelletier et al. 2011). In the present study, the higher $A_{\max }$ measured during summer 2008 and for June-July 2009 corresponded with decreased WTD; the increase in ecosystem productivity likely a result of vegetation responding to rising water table (Belyea and Clymo 1999). Under wetter than normal conditions, the Sphagnum spp. found on hummocks tend to increase productivity to grow away from the water table, in an attempt to reach a preferential position relative to the water table (Belyea and Clymo 1999; Bridgham et al. 2008). Humphreys et al. (2014) observed a decrease in GEP in bogs in the Hudson Bay lowlands during periods where the WTD was far from surface. Similarly, Sulman et al. (2010) previously showed that a temperate bog's GEP and ER increased as the WTD moved closer to the surface. At our site however, WTD influenced GEP only; no significant relationship was observed with ER. Lindroth et al. (2007) studied drivers of $\mathrm{C}$ exchange in a bog and three fens in Sweden and Finland. In the Fäjemyr bog in southern Sweden, they found that WTD influenced both GEP and ER but was correlated more strongly with GEP than ER. When their data were restricted to an initial drying phase they noted that WTD was correlated more strongly with ER than GEP at a fen in Kaamanen, Finland. WTD was found to be a significant driver for NEE in studies of Irish blanket bogs (e.g. McVeigh et al. 2014; Laine et al. 2007). However, the position of the water table was shown to be a less important driver of $\mathrm{C}$ exchange than other environmental variables (e.g. PAR, air/peat temperature) in a temperate bog (Mer Bleu, Canada; Lafleur et al. 2005; Teklemariam et al. 2010). Our study site is an ombrotrophic bog that is typical of those found in the James Bay lowlands, a peatland-rich sector of boreal Canada with a cold humid climate. Studies to date indicate that WTD may indeed broadly be a significant driver in a variety of peatlands but with the scarcity of long-term research sites in the boreal region, further work would be required to see if the findings presented here can be generalized to boreal peatlands.

Although the water table was also close to the surface in August and September 2009, the calculated
$A_{\max }$ was lower for these two months when compared to June and July 2009, and June to September 2008. The colder temperatures in August 2009 could explain the lower $A_{\max }$, as the monthly average temperature in August 2009 was $12.7^{\circ} \mathrm{C}$ compared to $15.5^{\circ} \mathrm{C}$ in 2008. The temperature went below the freezing point for two nights during the first 2 weeks and last week of August 2009, making August 2009 the coldest August of the 5 years. Lower temperature has been previously used to explain limited $\mathrm{CO}_{2}$ uptake (Harley et al. 1989). These colder temperatures could also have triggered earlier senescence (Smart 1994), potentially explaining the lower $A_{\max }$ also observed in September of that year, despite a mean temperature that was similar to 2008. The September 2009 WTD was less than in 2008 (44 mm compared to $59 \mathrm{~mm}$ ), reaching a level closest to the surface of all five summers. The relationship between WTD and productivity for peatland plant communities has been shown to follow a unimodal relationship, where maximum productivity is observed for a specific range of WTD. As the water table moves closer to or farther from the optimal range, a decrease in productivity results (Belyea and Clymo 1999). It is possible that the lower $A_{\max }$ measured in September 2009 is the result of WTD being close to the surface, above the optimal level for maximum productivity. The change in WTD also seems to have had a control on the June to August 2010 $A_{\text {max }}$ variability. In June 2010 , the WTD was $288 \mathrm{~mm}$ below surface, potentially as a result of an early snow melt and lower than normal precipitation (Figs. 1, 2). The water table slowly approached the surface through the rest of the summer, reaching similar levels to those observed in 2008 and 2009 by early August. This rise in water table coincides with the increase in $A_{\max }$ from June to August, suggesting that it was a limiting factor in early growing season photosynthesis (Figs. 1, 3). However, part of this increase in $A_{\max }$ between June and July 2010 is also likely linked with the vegetation reaching maximum photosynthesis capacity during mid-summer. While WTD seems to explain a great portion of the inter-annual variability in NEE and $A_{\text {max }}$, it is interesting to note that when WTD was further away from the surface in June 2010, $A_{\max }$ was still higher than any of the summer months in 2011 and 2012. A potential explanation for this could be that the April and May temperatures in 2010 were slightly higher than in 2011 and 2012, contributing to the earlier snowmelt and plant development. It is possible 
that the vegetation development therefore was more advanced in June 2010 compared to June 2011 and 2012, allowing high photosynthesis despite more limited water availability.

Although WTD represented a significant control on the variability of the $\mathrm{CO}_{2}$ sink in the studied boreal bog, other studies have found instead that temperature or timing of the snowmelt play a more important role in predicting the $\mathrm{CO}_{2}$ uptake capacity. For example, in a minerogenic peatland in Sweden, Peichl et al. (2014) found their growing season GEP to be strongly correlated with pre-growing season $\mathrm{T}_{\text {air }}$ suggesting that less root damage would occur during warmer winters and access to water by the vegetation would be easier. Similarly, in a mild maritime climate ombrotrophic bog, Helfter et al. (2015) found winter temperature to be a main control on the inter-annual variability in NEE. The reason why we do not observe such relationships at our site is likely attributed to the severity of the winter in boreal Quebec. The range in winter $\mathrm{T}_{\text {air }}$ at our site $\left(-15.0\right.$ to $\left.-8.6{ }^{\circ} \mathrm{C}\right)$ was much lower than that measured by Peichl et al. $(2014 ;-8$ to $-2{ }^{\circ} \mathrm{C}$ ) or Helfter et al. (2015), which rarely went below the freezing point. Our warmest pre-growing season temperature corresponds to the coldest at the fen studied by Peichl et al. (2014). Therefore, the proposed benefits of less root damage and easier water access as a result of warmer pre-growing season temperatures suggested by Peichl et al. (2014) are not likely to apply here as the frost penetration affects our site every year.

The timing of snow melt or onset of the growing season have also been shown to be important controls on the annual C uptake (Aurela et al. 2004; Sottocornola and Kiely 2010); both generally leading to greater NEP. We observed no relationships between the timing of the snowmelt or the beginning of the growing season, and the spring to fall, summer or annual NEP. While the absence of variation in our modeled winter NEE could be a potential cause for the lack of variability in our annual NEP evaluation, other studies have also shown limited inter-annual variability in winter $\mathrm{C}$ release. Over their 6 years of $\mathrm{CO}_{2}$ exchange measurements, Aurela et al. (2004) observed limited inter-annual variability in $\mathrm{C}$ winter release (23-26 $\mathrm{g} \mathrm{C} \mathrm{m}^{-2}$ ) and further found its contribution to inter-annual variability in NEP to be minor. While our winter $\mathrm{C}$ release numbers are smaller than those of Aurela et al. (2004), applying their range of values to our annual data would still not result in a significant effect; the timing of the snowmelt or the onset of growing season would still not represent an important control on the annual NEP.

The timing of snowmelt or the pre-growing season temperatures have each been shown to explain annual NEP in some temperate and subarctic peatlands but neither explained the inter-annual variability at our site. The timing of snowmelt and/or spring temperatures had an effect on the growing season start and the spring period NEP as shown by the largest $\mathrm{C}$ uptake in 2010. However, the effects of early snow melt and warmer temperatures were offset by lower $\mathrm{C}$ uptake compared with previous years (2008 and 2009) between June and September. This, therefore, suggests that the timing of snow melt and or spring temperatures could exert a significant control on annual NEP only if other environmental controls such as WTD remained similar between the years.

In our study region, the IPCC Fifth Assessment Report predicts an increase in both temperature and precipitation during the June-July-August period for 2081-2100, with respect to 1985-2006 data (Canadian climate data and scenarios; http://ccds-dscc.ec.gc.ca). The predicted increase in precipitation could lead to reduced WTD, which based on our results could lead to greater $\mathrm{CO}_{2}$ uptake. However, as WTD moves closer to the surface, $\mathrm{C}$ loss through $\mathrm{CH}_{4}$ release (Moore et al. 2011) and DOC export (Fraser et al. 2001), could counterbalance the greater $\mathrm{C}-\mathrm{CO}_{2}$ uptake. The predicted increase in temperature will also result in higher evaporation rates, which may offset the increased precipitation effect on WTD. Using the IPCC climate change scenarios (A1B, A2, B1, and Commit) and the CLASS3W-MWM peatland C model (Wu et al. 2012), Wu and Roulet (2014) evaluated the impact of climate change on a temperate bog's $\mathrm{C}$ exchange and found WTD to increase slightly with an increase in temperature and precipitation. Given the observed relationship between $A_{\max }$ and WTD, if this scenario of increasing depth to water table with climate warming also applies to boreal bogs, we could observe a reduction in $A_{\max }$ in northern peatlands.

\section{Conclusions}

The results presented here are among the few multiyear NEE measurements for northern peatlands. Our 
findings highlight the importance of WTD on the NEE in boreal bogs and stress the differences in controls on the inter-annual variability between peatland types; studies of other peatland types have observed significant responses with different variables such as timing of the growing season or snowmelt. The WTD represented the main explanatory variable at our site, explaining $92 \%$ of summer NEP inter-annual variability. The air temperature further explained the interannual summer cumulative $\mathrm{C}$ exchange variability, while also explaining the $\mathrm{C}$ exchange differences between springs and between monthly $A_{\max }$ when WTD were similar (e.g. August 2008 and 2009). As northern peatlands are dominated by bogs in boreal zones, results from previous studies focusing on different peatland types cannot be assumed to be transferrable. Furthermore, our results stress the high sensitivity of the peatland carbon exchange processes to changing environmental conditions, making them potential key players in future global $\mathrm{C}$ balance.

Acknowledgments This study was supported in part through NSERC Discovery and NSERC-CRD grants to IBS and through earlier funding from the Canadian Foundation for Climate and Atmospheric Sciences (CFCAS). Logistical support was provided by Hydro-Quebec Production and we thank Dr. A. Tremblay for his collaboration. We thank Dr. Onil Bergeron for guidance in data processing, and E. Doré, J. Dumoulin, J.-L. Fréchette, H. Higgins, L.-P. Potvin, C. Rogers and L. Winterhalt for their assistance in the field.

Open Access This article is distributed under the terms of the Creative Commons Attribution 4.0 International License (http:// creativecommons.org/licenses/by/4.0/), which permits unrestricted use, distribution, and reproduction in any medium, provided you give appropriate credit to the original author(s) and the source, provide a link to the Creative Commons license, and indicate if changes were made.

\section{References}

Amiro B (2010) Estimating annual carbon dioxide eddy fluxes using open-path analysers for cold forest sites. Agric For Meteorol 150:1366-1372

Aurela M, Laurila T, Tuovinen JP (2001) Seasonal $\mathrm{CO}_{2}$ balances of a subarctic mire. J Geophys Res 106:1623-1637

Aurela M, Laurila T, Tuovinen J-P (2002) Annual $\mathrm{CO}_{2}$ balance of a subarctic fen in northern Europe: importance of the wintertime efflux. J Geophys Res 107:4607. doi:10.1029/ 2002JD002055

Aurela M, Laurila T, Tuovinen J-P (2004) The timing of snow melt controls the annual $\mathrm{CO}_{2}$ balance in a subarctic fen. Geophys Res Lett 31:L16119. doi:10.1029/2004GL02 0315
Baldocchi D (1997) Flux footprints within and over forest canopies. Bound-Layer Meteorol 85:273-292. doi:10. 1023/A:1000472717236

Baldocchi DD (2003) Assessing the eddy covariance technique for evaluating carbon dioxide exchange rates of ecosystems: past, present and future. Glob Change Biol 9:479-492

Barr AG, Black TA, Hogg EH et al (2004) Inter-annual variability in the leaf area index of a boreal aspen-hazelnut forest in relation to net ecosystem production. Agric For Meteorol 126:237-255. doi:10.1016/j.agrformet.2004.06. 011

Belyea B, Clymo A (1999) Do hollows control the rate of peat bog growth? In: Standen V, Tallis J, Meade R (eds) Patterned mires and mire pools. British Ecological Society, London, pp 55-65

Bergeron O, Strachan IB (2011) $\mathrm{CO}_{2}$ sources and sinks in urban and suburban areas of a northern mid-latitude city. Atmos Environ 45:1564-1573

Bridgham SD, Pastor J, Dewey B et al (2008) Rapid carbon response of peatlands to climate change. Ecology 89:3041-3048

Burba GG, McDermitt DK, Grelle A et al (2008) Addressing the influence of instrument surface heat exchange on the measurements of $\mathrm{CO}_{2}$ flux from open-path gas analyzers. Glob Change Biol 14:1854-1876. doi:10.1111/J.13652486.2008.01606.X

Clymo RS (1984) The limits to peat bog growth. Philos Trans R Soc Lond B 303:605-654. doi:10.1098/rstb.1984.0002

Flanagan LB, Syed KH (2011) Stimulation of both photosynthesis and respiration in response to warmer and drier conditions in a boreal peatland ecosystem. Glob Change Biol 17:2271-2287. doi:10.1111/j.1365-2486.2010.02378.x

Fraser CJD, Roulet NT, Moore TR (2001) Hydrology and dissolved organic carbon biogeochemistry in an ombrotrophic bog. Hydrol Process 15:3151-3166. doi:10.1002/ hyp. 322

Frolking SE, Bubier JL, Moore TR et al (1998) Relationship between ecosystem productivity and photosynthetically active radiation for northern peatlands. Glob Biogeochem Cycles 12:115-126. doi:10.1029/97GB03367

Grelle A, Burba G (2007) Fine-wire thermometer to correct $\mathrm{CO}_{2}$ fluxes by open-path analyzers for artificial density fluctuations. Agr For Meteorol 147:48-57. doi:10.1016/J. Agrformet.2007.06.007

Harley PC, Tenhunen JD, Murray KJ, Beyers J (1989) Irradiance and temperature effects on photosynthesis of tussock tundra Sphagnum mosses from the foothills of the Philip Smith Mountains, Alaska. Oecologia 79:251-259. doi:10. 1007/BF00388485

Helfter C, Campbell C, Dinsmore KJ et al (2015) Drivers of long-term variability in $\mathrm{CO}_{2}$ net ecosystem exchange in a temperate peatland. Biogeosciences 12:1799-1811. doi:10.5194/bg-12-1799-2015

Hirata R, Hirano T, Saigusa N et al (2007) Seasonal and interannual variations in carbon dioxide exchange of a temperate larch forest. Agric For Meteorol 147:110-124. doi:10.1016/j.agrformet.2007.07.005

Humphreys ER, Charron C, Brown M, Jones R (2014) Two bogs in the Canadian Hudson Bay Lowlands and a temperate bog reveal similar annual net ecosystem exchange of $\mathrm{CO}_{2}$. 
Arct Antarct Alp Res 46:103-113. doi:10.1657/1938-4246. 46.1.103

Hutchinson MF, McKenney DW, Lawrence K et al (2009) Development and testing of Canada-wide interpolated spatial models of daily minimum-maximum temperature and precipitation for 1961-2003. J Appl Meteorol Climatol 48:725-741. doi:10.1175/2008JAMC1979.1

Koehler AK, Sottocornola M, Kiely G (2011) How strong is the current carbon sequestration of an Atlantic blanket bog? Glob Change Biol 17:309-319

Lafleur PM, Humphreys ER (2008) Spring warming and carbon dioxide exchange over low Arctic tundra in central Canada. Glob Change Biol 14:740-756. doi:10.1111/j.1365-2486. 2007.01529.x

Lafleur PM, Griffis TJ, Rouse WR (2001) Interannual variability in net ecosystem $\mathrm{CO}_{2}$ exchange at the arctic treeline. Arct Antarct Alp Res 33:149-157

Lafleur PM, Roulet NT, Bubier JL et al (2003) Interannual variability in the peatland-atmosphere carbon dioxide exchange at an ombrotrophic bog. Glob Biogeochem Cycles 17:1036. doi:10.1029/2002GB001983

Lafleur PM, Moore TR, Roulet NT, Frolking S (2005) Ecosystem respiration in a cool temperate bog depends on peat temperature but not water table. Ecosystems 8:619-629. doi:10.1007/s10021-003-0131-2

Laine A, Byrne KA, Kiely G, Tuittila E-S (2007) Patterns in vegetation and $\mathrm{CO}_{2}$ dynamics along a water level gradient in a lowland blanket bog. Ecosystems 10:890-905. doi:10. 1007/s10021-007-9067-2

Lindroth A, Lund M, Nilsson M et al (2007) Environmental controls on the $\mathrm{CO}_{2}$ exchange in north European mires. Tellus 59b:812-825

Lloyd J, Taylor JA (1994) On the temperature dependence of soil respiration. Funct Ecol 8:315-323. doi:10.2307/ 2389824

Lund M, Lafleur PM, Roulet NT et al (2010) Variability in exchange of $\mathrm{CO}_{2}$ across 12 northern peatland and tundra sites. Glob Change Biol 16:2436-2448

MacDonald GM, Beilman DW, Kremenetski KV et al (2006) Rapid early development of circumarctic peatlands and atmospheric $\mathrm{CH}_{4}$ and $\mathrm{CO}_{2}$ variations. Science 314:285-288. doi:10.1126/Science.1131722

McVeigh P, Sottocornola M, Foley N et al (2014) Meteorological and functional response partitioning to explain interannual variability of $\mathrm{CO}_{2}$ exchange at an Irish Atlantic blanket bog. Agric For Meteorol 194:8-19

Mkhabela MS, Amiro BD, Barr AG et al (2009) Comparison of carbon dynamics and water use efficiency following fire and harvesting in Canadian boreal forests. Agr For Meteorol 149:783-794. doi:10.1016/J.Agrformet.2008.10.025

Moore TR, De Young A, Bubier JL et al (2011) A multi-year record of methane flux at the Mer Bleue bog, southern Canada. Ecosystems 14:646-657

Morgenstern K, Andrew Black T, Humphreys ER et al (2004) Sensitivity and uncertainty of the carbon balance of a Pacific Northwest Douglas-fir forest during an El Niño/La Niña cycle. Agric For Meteorol 123:201-219. doi:10.1016/ j.agrformet.2003.12.003

Nilsson M, Sagerfors J, Buffam I et al (2008) Contemporary carbon accumulation in a boreal oligotrophic minerogenic mire-a significant sink after accounting for all C-fluxes. Glob Change Biol 14:2317-2332

Peichl M, Öquist M, Löfvenius MO et al (2014) A 12-year record reveals pre-growing season temperature and water table level threshold effects on the net carbon dioxide exchange in a boreal fen. Environ Res Lett 9:055006. doi:10.1088/1748-9326/9/5/055006

Pelletier L, Garneau M, Moore TR (2011) Variation in $\mathrm{CO}_{2}$ exchange over three summers at microform scale in a boreal bog, Eastmain region, Québec, Canada. J Geophys Res 116:G03019. doi:10.1029/2011JG001657

Roulet NT, Lafleur PM, Richard PJH et al (2007) Contemporary carbon balance and late Holocene carbon accumulation in a northern peatland. Glob Change Biol 13:397-411. doi:10. 1111/J.1365-2486.2006.01292.X

Sagerfors J, Lindroth A, Grelle A et al (2008) Annual $\mathrm{CO}_{2}$ exchange between a nutrient-poor, minerotrophic, boreal mire and the atmosphere. J Geophys Res 113:G01001. doi:10.1029/2006JG000306

Smart CM (1994) Gene expression during leaf senescence. New Phytol 126:419-448. doi:10.1111/j.1469-8137.1994.tb04243.x

Sottocornola M, Kiely G (2010) Hydro-meteorological controls on the $\mathrm{CO}_{2}$ exchange variation in an Irish blanket bog. Agric For Meteorol 150:287-297. doi:10.1016/j.agrformet.2009. 11.013

Sulman BN, Desai AR, Saliendra NZ et al (2010) $\mathrm{CO}_{2}$ fluxes at northern fens and bogs have opposite responses to interannual fluctuations in water table. Geophys Res Lett. doi:10.1029/2010g1044018

Tarnocai C (2006) The effect of climate change on carbon in Canadian peatlands. Glob Planet Change 53:222-232

Teklemariam T, Lafleur P, Moore TR et al (2010) The direct and indirect effects of inter-annual meteorological variability on ecosystem carbon dioxide exchange at a temperate ombrotrophic bog. Agric For Meteorol 150:1402-1411

Van Bellen S, Dallaire P-L, Garneau M, Bergeron Y (2011) Quantifying spatial and temporal Holocene carbon accumulation in ombrotrophic peatlands of the Eastmain region, Quebec, Canada. Glob Biogeochem Cycles 25:GB2016. doi:10.1029/2010GB003877

Vickers D, Mahrt L (1997) Quality control and flux sampling problems for tower and aircraft data. J Atmos Ocean Technol 14:512-526. doi:10.1175/15200426(1997)014<0512:QCAFSP > 2.0.CO;2

Webb EK, Pearman GI, Leuning R (1980) Correction of flux measurements for density effects due to heat and watervapor transfer. Q J R Meteorol Soc 106:85-100

Wu J, Roulet NT (2014) Climate change reduces the capacity of northern peatlands to absorb the atmospheric carbon dioxide: the different responses of bogs and fens. Glob Biogeochem Cycles 28:1005-1024. doi:10.1002/ 2014GB004845

Wu J, Roulet NT, Nilsson M et al (2012) Simulating the carbon cycling of northern peatlands using a land surface scheme coupled to a wetland carbon model (CLASS3WMWM). Atmos Ocean 50:487-506. doi:10.1080/ 07055900.2012.730980

Yu Z, Loisel J, Brosseau DP et al (2010) Global peatland dynamics since the last glacial maximum. Geophys Res Lett 37:L13402. doi:10.1029/2010GL043584 
Yu Z, Loisel J, Turetsky MR et al (2013) Evidence for elevated emissions from high-latitude wetlands contributing to high atmospheric $\mathrm{CH}_{4}$ concentration in the early Holocene.
Glob Biogeochem Cycles 27:131-140. doi:10.1002/gbc. 20025 